ISSN 0258-7122

Bangladesh J. Agril. Res. 34(3) : 411-416, September 2009

\title{
EFFECT OF DIFFERENT LEVELS OF NAA ON IN VITRO GROWTH AND DEVELOPMENT OF SHOOTS OF DENDROBIUM ORCHID
}

\author{
M. S. PARVIN ${ }^{1}$, M. E. HAQUE ${ }^{2}$, F. AKHTER ${ }^{3}$ \\ MONIRUZZAMAN $^{4}$ AND A.B.M. KHALDUN ${ }^{5}$
}

\begin{abstract}
The present study was conducted to investigate the effect of growth regulator NAA on in vitro shoot proliferation, rooting, and plantlet establishment. Among the different concentrations of NAA, the best increase in shoot weight $(0.25 \mathrm{~g})$ and shoot number (8.83) were observed from $0.1 \mathrm{mg} / \mathrm{I}$ NAA. The highest shoot length $(2.60 \mathrm{~cm})$, number of leaves $(4.83)$, number of roots $(5.15)$, and root length $(2.67 \mathrm{~cm})$ were obtained with $0.2 \mathrm{mg} / \mathrm{I} \mathrm{NAA}$ at $60 \mathrm{DAT}$.
\end{abstract}

Key Words : Dendrobium orchid, NAA, MS media.

\section{Introduction}

The orchids are one of the most beautiful flower producing plants in the world. These extraordinary plants belong to the family Orchidaceae having more than 25,000 species and 700-800 genera which constitutes probably the largest family among the flowering plants and exhibit an almost innumerable hybrids and inexhaustible varieties. Orchids grow over a wide range of climatic conditions (Hatch, 1953). The environmental conditions required for the survival and culture of orchids are adequately available throughout the year in Bangladesh. Dendrobium is one of the largest diverse genera of orchid and has supplied the second largest number of species in the orchidaceae family and comprises about 1600 species distributed in India, Burma, Malaysia, Australia, New Zealand, China, and Japan (Bose and Bhattacharyee, 1980). There is a great range of variation in the principle characteristic of the genus e.g. size, habit, form of stem and leaf and shape and colour of flowers. Dendrobium, in general, grow well in perforated earthen pots. Several species with dropping pendent habit are potted in baskets, whereas other species with creeping stem or dwarf to small types are grown on tree fern blocks (Bose and Bhattacharyee, 1980). Micropropagation of orchids is well known for its potential exploitation as a major trade in developed countries (Fu, 1979; Morel, 1964; Goh, 1982; Sagawa and Kunisaki, 1982). When mass propagation of a new hybrid or a variety is needed within a short time, tissue culture is the only option (Morel, 1960; Hadley, 1970; Healy et al.,

\footnotetext{
${ }^{1 \& 5}$ Scientific Officer, Plant Breeding Division, BARI, Joydebpur, Gazipur-1701, ${ }^{2}$ Scientific Officer, TCRC, BARI, Joydebpur, Gazipur-1701, ${ }^{4}$ Scientific Officer, Biotechnology Division, BARI, Joydebpur,Gazipur-1701, ${ }^{3}$ Research Fellow, BAU, Mymensingh-2202, Bangladesh.
} 
1980; Goh et al., 1992). This is because mass propagation of orchid in commercial exploitation is possible by tissue culture techniques (Lim et al., 1985). On the other hand, using traditional method of propagation, only a very limited number of plants can be produced. In vitro production of shoots is easy and a large number of mini plants can be produced within a short time. However, their proliferation, rooting and acclimatization are relatively difficult and time consuming. Keeping these views in mind, the present research has been considered to study the rooting and acclimatization of Dendrobium plantlet grown in vitro with supplementation of $\alpha$ - Naphthalene acetic acid (NAA) into MS media.

\section{Materials and Method}

To study the development of shoot, rooting and plantlet establishment, in vitro regenerated $1 \mathrm{~cm}$ shoot with two leaves of Dendrobium orchid were collected and studied during the period from July to November 2006 in the Biotechnology Laboratory, Department of Biotechnology, Bangladesh Agricultural University, Mymensingh. The experiment was conducted with different concentrations $(0$, 0.1 , and $0.2 \mathrm{mg} / \mathrm{I}$ ) of hormone supplementation as treatments in MS (Murashige and Skoog, 1962) media to obtain proper growth of shoots and development of roots. Prior to medium preparation, five stock solutions like stock solution of macronutrients, micronutrients, iron source/Fe-EDTA, vitamins/organics and plant growth regulator were prepared. Stock solution of Macronutrients was prepared 10 times of desired concentration with distilled water. Required salts $\left(\mathrm{KNO}_{3}-1.90 \mathrm{~g} / \mathrm{L}, \mathrm{NH}_{4} \mathrm{NO}_{3}-1.650 \mathrm{~g} / \mathrm{L}, \mathrm{MgSO}_{4} \cdot 7 \mathrm{H}_{2} \mathrm{O}-0.370 \mathrm{~g} / \mathrm{L}, \mathrm{CaCl}_{2} .2 \mathrm{H}_{2} 0-\right.$ $0.440 \mathrm{~g} / \mathrm{L}, \mathrm{KH}_{2} \mathrm{PO}_{4}-0.170 \mathrm{~g} / \mathrm{L}$ ) were taken in a conical flask and was dissolved in distilled water using a magnetic stirrer.

Finally, required distilled water was added upto the mark. Prepared solution was kept in a glass container, labeled with marker and stored in a refrigerator at $4^{\circ} \mathrm{C}$ for later use. The stock solution of micronutrients $\left(\mathrm{MnSO}_{4} 4 \mathrm{H}_{2} \mathrm{O}-22.3 \mathrm{mg} / \mathrm{L}\right.$, $\mathrm{H}_{3} \mathrm{BO}_{3}-6.2 \mathrm{mg} / \mathrm{L}, \mathrm{ZnSO}_{4} 7 \mathrm{H}_{2} \mathrm{O}-8.6 \mathrm{mg} / \mathrm{L}, \mathrm{Na} 2 \mathrm{MoO}_{4} 2 \mathrm{H}_{2} \mathrm{O}-0.25 \mathrm{mg} / \mathrm{L}, \mathrm{CuSO}_{4} 5 \mathrm{H}_{2} \mathrm{O}-$ $0.025 \mathrm{mg} / \mathrm{L}, \mathrm{CoCl}_{2} .6 \mathrm{H}_{2} 0-0.025 \mathrm{mg} / \mathrm{L}, \mathrm{KI}-0.83 \mathrm{mg} / \mathrm{L}$ ) was made up to 100 times higher strength. The stock solution of iron source $\left(\mathrm{FeSO}_{4}-27.8 \mathrm{mg} / \mathrm{L}\right.$ and $\mathrm{Na}_{2}$ EDTA $2 \mathrm{H}_{2} 0-37.3 \mathrm{mg} / \mathrm{L}$ ) were dissolved in $750 \mathrm{ml}$ of distilled water in a conical flask by heating in a water bath until the salts dissolved completely and final volume was made upto one litre by further addition of distilled water. This stock was also filtered and stored in refrigerator at $4{ }^{\circ} \mathrm{C}$. The stock solution of vitamins, namely Pyridoxine $\mathrm{HC1}$, thiamine $\mathrm{HCl}$ (vitamin $\mathrm{B}_{1}$ ), glycine and nicotinic acid (vitamin $\mathrm{B}_{3}$ ) were prepared 100 times the concentration of their final strength and stored at $-20^{\circ} \mathrm{C}$ in $10 \mathrm{ml}$ aliquots. Separate stock solutions of PGR ( $\alpha$ - Naphthalene acetic acid), $10 \mathrm{mg}$ of solid hormone was taken in a $100 \mathrm{ml}$ clean beaker and then dissolved in $1 \mathrm{ml}$ of $0.1 \mathrm{~N} \mathrm{NaOH}$ solvent. Then the volume 
was made $100 \mathrm{ml}$ by the addition of distilled water to get $100 \mathrm{mg} / \mathrm{I}$ solution. The required volume of each stock solution $(100 \mathrm{ml}$ macro nutrients, $10 \mathrm{ml}$ iron source, $10 \mathrm{ml}$ micro nutrients, $10 \mathrm{ml}$ vitamin) was poured into 4 beakers and mixed. About $200 \mathrm{ml}$ distilled water was added to this. Then $100 \mathrm{mg}$ of myoinositol was added directly to the solution and dissolved well. After that 30 $\mathrm{mg}$ of sucrose was added to this solution and gently agitated to dissolve completely. The solution was poured into a $1000 \mathrm{ml}$ measuring cylinder and the volume was made upto $1000 \mathrm{ml}$. For this experiment, this solution was poured into 3 beakers taking $300 \mathrm{ml}$ of the solution in each beaker. Required volume of PGR solution was directly added to the solutions in the beakers. The $\mathrm{pH}$ of the solutions were adjusted to 5.8 with a digital $\mathrm{pH}$ meter with the help of $0.1 \mathrm{~N}$ $\mathrm{NaOH}$ or $0.1 \mathrm{~N} \mathrm{HC1}$ as necessary.

After adjusting the $\mathrm{pH}, 6.3 \mathrm{~g}$ of agar was divided into 3 groups and in each solution, thus $2.1 \mathrm{~g}$ of agar was added to each mixture and was then gently heated in a hot plate magnetic stirrer till complete dissolution of agar took place. Care was taken so that the solution did not get boil while melting agar. About $25 \mathrm{ml}$ of warm media was dispensed into each of small vials, by this way 12 vials were taken for each treatment and the culture vessels containing the media were autoclaved with $1.16 \mathrm{~kg} / \mathrm{cm}^{2}$ of pressure at $121^{\circ} \mathrm{C}$ for 20 minutes. After autoclaving the culture vessels containing the culture media were allowed to cool. The culture vials for three NAA levels were arranged in each DAI separately and closed with black plastic caps and marked to indicate specific treatment. The culture vials were maintained in a growth room and allowed to grow at $25 \pm 1^{\circ} \mathrm{C}$ under 16 hours photoperiod illuminated with fluorescent tube of 2000-3000 lux. After 20, 40, and 60 days of inoculation, the plantlets were taken out from the vial and the following parameters, namely weight of shoot, number of shoots, shoot length, number of leaves per plantlet, number of roots per plantlet, root length data were recorded. The data for the characters under the present study were statistically analyzed following Completely Randomized Design (CRD). The analysis of variance was performed and means were compared by Least Significant Difference (LSD) test at 5\% level of probability for interpretation of results (Gomez and Gomez, 1984).

\section{Hardening processes of in vitro grown plantlets}

At first, the plantlets with well developed roots were separated from the culture vials without damaging the roots. The media adhering to the roots were washed in running tap water. After washing the roots, the plantlets were transferred to potting media and then they were kept in room temperature for 7 days. After 7 days, the plantlets were shifted to hardening room. After hardening, the plantlets could be transferred to orchid house. 


\section{Results and Discussion}

Significant variation was found in weight of shoots at different concentrations of NAA at different days after inoculation (DAT). The weight of shoots was found to increase gradually at different DAT, where the highest weight of shoot was obtained from $0.1 \mathrm{mg} / \mathrm{L}$ NAA and at all DAI followed by $0.2 \mathrm{mg} / \mathrm{L}$ NAA and the lowest from control. The present findings on shoot weight is in agreement with Lee et al.(1999) who reported that well developed shoots were found at $0.1 \mathrm{mg} / \mathrm{L}$ NAA, and the orchid seedlings died in presence of higher concentration of NAA $(1 \mathrm{mg} / \mathrm{L})$.

Table 1. Effect of different levels of NAA on in vitro growth and development of Dendrobium plantlets.

\begin{tabular}{|c|c|c|c|c|c|c|c|c|c|c|c|c|}
\hline \multirow{3}{*}{$\begin{array}{c}\mathrm{NAA} \\
(\mathrm{mg} / \mathrm{I})\end{array}$} & \multicolumn{3}{|c|}{ Weight of shoot $(\mathrm{g})$} & \multicolumn{3}{|c|}{ Number of shoots } & \multicolumn{3}{|c|}{ Number of leaves } & \multicolumn{3}{|c|}{ Root length (cm) } \\
\hline & 20 & 40 & 60 & 20 & 40 & 60 & 20 & 40 & 60 & 20 & 40 & 60 \\
\hline & DAI & DAI & DAI & DAI & DAI & DAI & DAI & DAI & DAI & DAI & DAI & DAI \\
\hline 0.0 & $0.10 \mathrm{~b}$ & $0.13 \mathrm{c}$ & $0.16 \mathrm{c}$ & $5.08 \mathrm{~b}$ & $6.25 \mathrm{~b}$ & $6.92 \mathrm{c}$ & $2.00 \mathrm{~b}$ & $2.58 b$ & $3.38 \mathrm{~b}$ & $0.68 \mathrm{c}$ & $087 \mathrm{c}$ & $1.10 \mathrm{c}$ \\
\hline 0.1 & $0.16 \mathrm{a}$ & $0.20 \mathrm{a}$ & $0.25 \mathrm{a}$ & $5.50 a$ & $7.17 \mathrm{a}$ & $8.83 a$ & $3.00 \mathrm{a}$ & $3.83 a$ & $4.68 \mathrm{a}$ & $120 b$ & $1.63 b$ & $2.07 \mathrm{~b}$ \\
\hline 0.2 & $0.16 \mathrm{a}$ & $0.19 b$ & $0.24 b$ & $5.08 \mathrm{~b}$ & $6.42 \mathrm{~b}$ & $7.83 b$ & $3.17 \mathrm{a}$ & $4.00 \mathrm{a}$ & $4.83 \mathrm{a}$ & $2.08 \mathrm{a}$ & $2.33 \mathrm{a}$ & $2.67 \mathrm{a}$ \\
\hline $\operatorname{LSD}(5$ & o) 0.003 & 0.003 & 0.003 & 0.411 & 0.456 & 0.541 & 0.180 & 0.283 & 0.231 & 0.075 & 0.074 & 0.096 \\
\hline $\mathrm{CV}(\%)$ & 5.77 & 6.98 & 3.87 & 9.40 & 8.23 & 8.21 & 7.87 & 9.71 & 6.42 & 6.70 & 5.40 & 5.89 \\
\hline
\end{tabular}

Mean values followed by a common letter in a column are not significantly different at the $5 \%$ level by LSD

Number of shoots was significantly influenced by different concentrations of NAA at different DAI. At 40 DAI, the maximum number of shoots (7.17) was recorded in $0.1 \mathrm{mg} / \mathrm{L}$ NAA. Results indicated that the number of plantlets is increased with the passage of time. At $60 \mathrm{DAI}$, the highest number of shoots (8.83) was obtained from $0.1 \mathrm{mg} / \mathrm{L}$ NAA and the lowest (6.92) from control treatment (Table 1). Rahman (2001) found the highest number of regenerated plantlets (4.66/vial) with the supplementation of $0.5 \mathrm{mg} / \mathrm{L}$ NAA in Doritaenopsis orchid. In the present study, comparatively high number (8.83) of shoots was found with lower level of NAA. This might be due to a different genus of orchids in the present study. NAA significantly increased the length of shoots as was assessed at 20,40, and 60 DAI. In general, shoot length and number of leaves increased with the age of plant. The NAA concentration of $0.2 \mathrm{mg} / \mathrm{L}$ produced the longest shoots and maximum roots followed by $0.1 \mathrm{mg} / \mathrm{L}$ and control (Fig 1 and Fig. 2) in all age groups. This result was supported by that of Prasad et al. (2001) who reported that NAA influences the number of roots in orchid. 

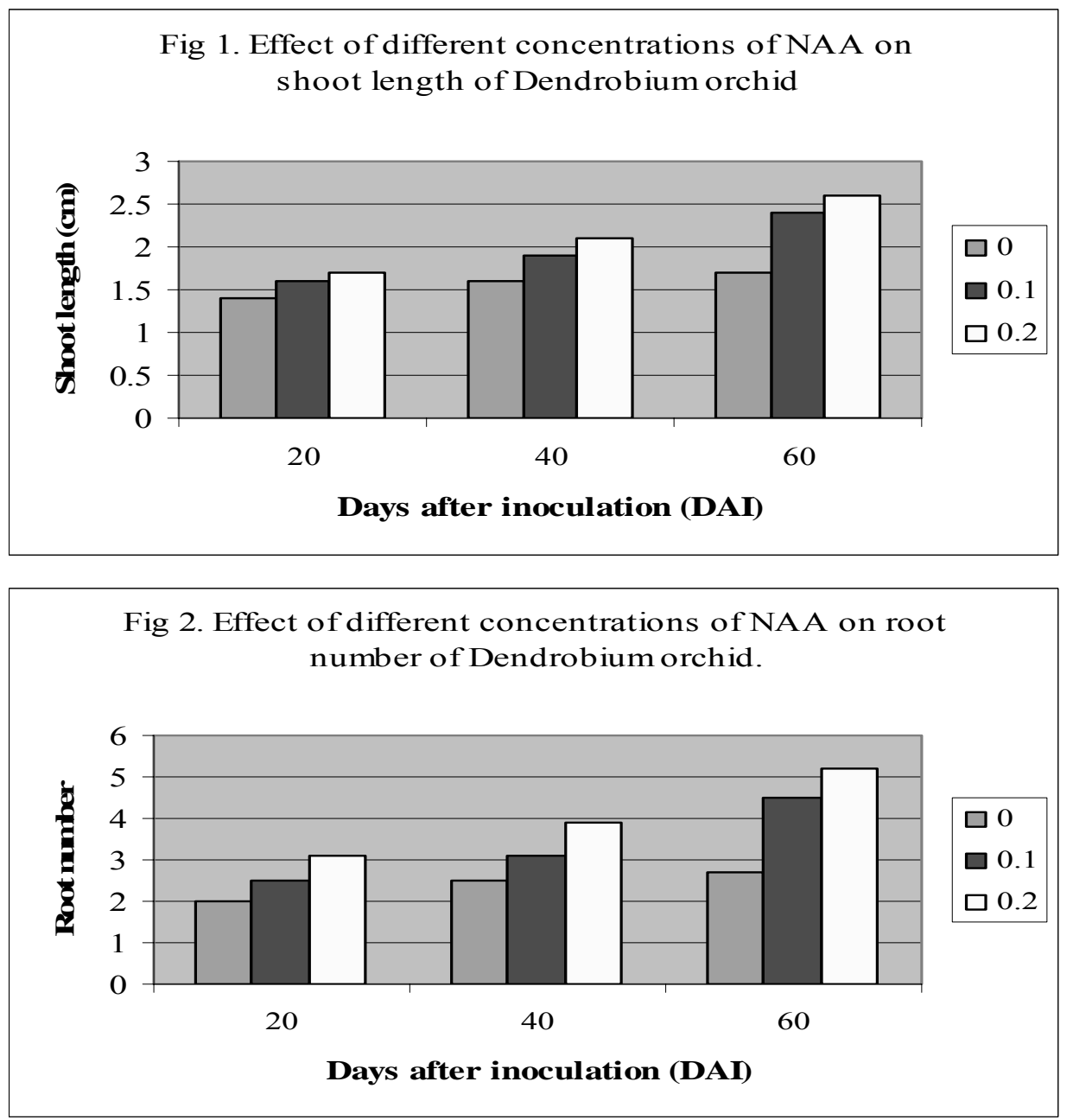

It was observed that the higher concentration of NAA gave the longer shoots. It indicated that more higher concentrations of NAA might be more effective for shoot elongation.

The number of leaves also increased with DAI. However both $0.1 \mathrm{mg} / \mathrm{L}$ and $0.2 \mathrm{mg} / \mathrm{L}$ NAA had statistically identical effect on leaf number (Table 1). Maximum number of leaves was obtained at 60 DAI from these treatments compared to control.

A significant difference was found on root length increased with the increase of DAIs irrespective of the treatments. The maximum root length was obtained from $0.2 \mathrm{mg} / \mathrm{L}$ NAA at all three DAI followed by $0.1 \mathrm{mg} / \mathrm{L}$ NAA and control (Table 1). Vij et al. (1989) found a positive effect of NAA on rooting of multiplied shoots. 


\section{References}

Bose, T.K. and S.K. Bhattacharjee. 1980. Orchids of India. Naya Prokash. Calcutta, India. pp. 25-26.

Fu, F.M.L. 1979. Studies yn the tissue culture of orchids. Macdonald and Co. Ltd., Great Britain, pp. 1015-1016.

Goh, C.J. and H. Tan. 1982. Clonal propagation from leaf explants in Renantanda orchid. Hybrid Orchid Rev. 90: 295-296.

Goh, C.J., A.A. Sim and G. Lim. 1992. Mycorrhizal associations in some tropical orchids. Lindleyana 7(1): 13-17.

Gomez, K.A. and A.A. Gomez. 1984. Statistical Procedure for Agricultural Research (2' edition). Willey Intl. Sci. Pub., pp. 28-192.

Hadley, G. 1970. The interaction of leinetin, auxin and other factors in the development of North Temperate Orchid. New Phytol. 69: 549-555.

Hatch, E.D. 1953. Oquideas subterraneas. Orquidea 15(1): 2-11.

Healey, P.L., J.D. Michaud and J. Ariditti. 1980. Morphometry of Orchid seeds. III. Native California and related species of Goodeyera, Piperia, Plantanthera and Spiranthes. Amer. J. Bot. 97: 508-518.

Lee, J.S., J.M. Lee, I.S. So and K.W. Kang. 1999. Effect of medium and plant growth regulators on in vitro growth of Sarcanthus scolopendrjfolius. J. Korean Soc. Hort. Sci. 40(6): 742-746.

Lim-Ho, C.L., G.C. Lee and L.K. Phua. 1985. Clonal propagation of orchids from flower buds. Proc. Asian orchid Cong. Ed. A.N. Rao, Singapore, p.90-110.

Morel, G. 1960. Producing virus free Cymbidiums. Amer. Orchid Soc. Bull., 19: 495497.

Morel, G. 1964. Tissue culture: A new means of clonal propagation of orchids. Amer. Orchid Soc. Bull. 33: 473-478.

Murashige, T. and F. Skoog. 1962. A revised medium for rapid growth and bioassays with tobacco tissue cultures. Physiol. Plant. 15: 473-497.

Prasad, G.V.S.S., I.V.S. Rao and P.V. Reddy. 2001. In vitro propagation of orchid Dendrobium cv. Sonia. India J. Plant Physiol. 6(3): 284-288.

Rahman, A.R.M.M. 2001. Studies on the improvement of in vitro plantlet regeneration in Dorieaenopsis and Cattleya orchids. MS Thesis, Dept. of Crop Bot., Bangladesh Agricultural University, Mymensingh.

Sagawa, Y. and J.T. Kunisaki. 1982. Clonal propagation of orchids by tissue culture. In: Plant Tissue Culture, A Fujiwara, Maruzen, Tokyo, p. 683-864.

Vij, S.P., Promilapathak and P. Pathak. 1989. Micropropagation of Dendrobium chrysant hum Wall. through pseudobulb segments. J. Orchid Soc. India 3(1-2): 25-28. 